ARTICLE

Received 28 Feb 2014 | Accepted 22 May 2014 | Published 18 Jun 2014 DOI: 10.1038/ncomms5197

\title{
Source identification of the Arctic sea ice proxy $\mathrm{IP}_{25}$
}

\author{
T.A. Brown ${ }^{1}$, S.T. Belt ${ }^{1}$, A. Tatarek ${ }^{2} \&$ C.J. Mundy ${ }^{3}$
}

Analysis of the organic geochemical biomarker $\mathrm{IP}_{25}$ in marine sediments is an established method for carrying out palaeo sea ice reconstructions for the Arctic. Such reconstructions cover timescales from decades back to the early Pleistocene, and are critical for understanding past climate conditions on Earth and for informing climate prediction models. Key attributes of $\mathrm{IP}_{25}$ include its strict association with Arctic sea ice together with its ubiquity and stability in underlying marine sediments; however, the sources of $\mathrm{IP}_{25}$ have remained undetermined. Here we report the identification of $\mathrm{IP}_{25}$ in three (or four) relatively minor $(<5 \%)$ sea ice diatoms isolated from mixed assemblages collected from the Canadian Arctic. In contrast, $\mathbb{I P}_{25}$ was absent in the dominant taxa. Chemical and taxonomical investigations suggest that the $\mathrm{IP}_{25}$-containing taxa represent the majority of producers and are distributed pan-Arctic, thus establishing the widespread applicability of the $\mathrm{IP}_{25}$ proxy for palaeo Arctic sea ice reconstruction.

\footnotetext{
${ }^{1}$ Biogeochemistry Research Centre, School of Geography, Earth and Environmental Sciences, University of Plymouth, Plymouth PL4 8AA, UK. ${ }^{2}$ Institute of Oceanology Polish Academy of Sciences, Powstańców Warszawy 55, 81-712 Sopot, Poland. ${ }^{3}$ Centre for Earth Observation Science, University of Manitoba, 535 Wallace Building, 125 Dysart Road, Winnipeg, Canada R3T 2N2. Correspondence and requests for materials should be addressed to T.A.B. (email: thomas.brown@plymouth.ac.uk).
} 
$\mathrm{T}$ he reconstruction of sea ice conditions in the polar regions represents a key objective within palaeoceanography and palaeoclimatology ${ }^{1}$. This is largely owing to the major role that sea ice has in controlling the energy budget at the Earth's surface, due to its high albedo, and also since it limits heat, gas and moisture exchange between the oceans and the atmosphere ${ }^{2,3}$. Further, sea ice contributes to ocean ventilation and circulation via brine rejection and freshwater input, following formation and melting, respectively ${ }^{2}$.

Performing such reconstructions is challenging, however, since sea ice itself leaves no direct legacy signature in geological archives, necessitating the use of so-called proxy methods. A number of proxies for sea ice exist and these are both biogenic ${ }^{1}$ and non-biogenic in origin ${ }^{4-6}$. Within the former category, the recent discovery of the organic geochemical biomarker $\mathrm{IP}_{25}$ (ref. 7) (a $\mathrm{C}_{25}$ highly branched isoprenoid (HBI) lipid $^{8}$ ) has attracted considerable interest, not least because it possesses the unique attribute of being produced within the sea ice itself. Consistent with this sea ice origin, the occurrence of $\mathrm{IP}_{25}$ in marine sediments shows a strong correlation, spatially, to seasonally ice-covered Arctic waters ${ }^{9}$, and, from a temporal perspective, $\mathrm{IP}_{25}$ appears to be stable in sediments for millions of years ${ }^{10}$. Combined, these attributes of $\mathrm{IP}_{25}$ have provided the foundation for decadal to millennial-scale sea ice reconstructions across the Arctic ${ }^{9-15}$.

Despite these interesting and valuable applications of the $\mathrm{IP}_{25}$ sea ice proxy, the source organisms responsible for formation of this lipid in sea ice have remained elusive. A diatom source has been proposed ${ }^{7,16}$, however, since $\mathrm{IP}_{25}$ has been reported in Arctic sea ice biota dominated by diatoms ${ }^{16,17}$ and similar lipids occur in some non-sea ice algae ${ }^{18-22}$. More specifically, it has been hypothesized that sea ice diatoms belonging to the Haslea genus are likely producers of $\mathrm{IP}_{25}$ on the basis of biosynthesis of related biomarkers by such species ${ }^{7,16,17,23-25}$. Nevertheless, $\mathrm{IP}_{25}$ has never been reported in any cultures of diatoms, including some Haslea species isolated from Arctic sea ice ${ }^{9}$. Arguably, until the sources of $\mathrm{IP}_{25}$ have been determined, together with information regarding their distributions across the Arctic, the potential for $\mathrm{IP}_{25}$ as a palaeo sea ice proxy cannot be fully realized.

In the current study, we identify three (or four) sea ice endemic diatom species that are responsible for $\mathrm{IP}_{25}$ production in Canadian Arctic sea ice during a spring bloom. We achieve this by isolation of individual cells from mixed sea ice diatom assemblages and analysis of their lipid composition by gas chromatography-mass spectrometry (GC-MS). The identified $\mathrm{IP}_{25}$ producers (Pleurosigma stuxbergii var. rhomboides (Cleve in Cleve and Grunow) Cleve, Haslea kjellmanii (Cleve) Simonsen, H. crucigeroides (Hustedt) Simonsen and/or H. spicula (Hickie) Lange-Bertalot) constitute a relatively minor proportion of the ice taxa, but, significantly, they are nonetheless common pan-Arctic species that validate the notion that $\mathrm{IP}_{25}$ represents a widespread proxy for palaeo Arctic sea ice.

\section{Results}

Identification of $\mathrm{IP}_{25}$ producers. Taxonomic assessment of the diatom assemblage within several algal aggregates from Resolute Bay in the Canadian Arctic revealed a distinctive flora, characteristic of sea ice ${ }^{26-28}$. Thus, the three most abundant species were Navicula pelagica (ca.40-50\%), Nitzschia frigida (ca. $10-20 \%$ ) and Pauliella taeniata (ca. 10-20\%) (Table 1), with a near absence of planktic cells $(<0.5 \%)$. From one assemblage (SIA-1), we isolated and combined sufficient numbers of cells from (at least) six individual species to perform quantitative lipid analysis by GC-MS to show that $\mathrm{IP}_{25}$ was present in P. stuxbergii var. rhomboides and at least two species from the genus Haslea (H. kjellmanii, H. crucigeroides and/or H. spicula) (Fig. 1), but was absent in other important ice algal species; $N$. pelagica, N. frigida, and Entomoneis paludosa (Fig. 1 and Table 2).

The occurrence of $\mathrm{IP}_{25}$ in $\mathrm{H}$. crucigeroides (and/or H. spicula) and $H$. kjellmanii is consistent with the production of other HBIs by members of the genus Haslea ${ }^{18,19,25,29-31}$, which led to the previous suggestion that Haslea was a likely source of $\mathrm{IP}_{25}$ in Arctic sea ice $7,16,23,24$, despite the failure for such species to produce $\mathrm{IP}_{25}$ in culture ${ }^{29}$. The identification of $P$. stuxbergii var. rhomboides as an $\mathrm{IP}_{25}$ producer is also consistent with the formation of other HBIs by several Pleurosigma diatoms ${ }^{20,32}$, although we are unaware of any reports describing the HBI content of $P$. stuxbergii var. rhomboides, per se. In contrast, $\mathrm{IP}_{25}$ was absent in at least two of the typically abundant ice flora ( $\mathrm{viz}$, $N$. pelagica and $N$. frigida), supporting the notion that $\mathrm{IP}_{25}$ is produced selectively by a limited number of Arctic sea ice diatom taxa $7,16,23,24$. Indeed, the same conclusion was reached following taxonomic analysis and lipid characterization of mixed diatom assemblages in sectioned sea ice cores collected from the same location as the samples described here ${ }^{16}$.

Previously, it has been shown that, although the physiology of diatom genera can be important for production of HBIs, not all species within such genera are HBI producers. Thus, some species within the Haslea, Pleurosigma and Navicula genera are known HBI producers, but others are not. For example, species such as $H$. ostrearia ${ }^{18}$ and $P$. intermedium ${ }^{32}$ produce HBIs, but H. wawrikae and P. angulatum do not ${ }^{29}$. Within the current context, we note that $\mathrm{IP}_{25}$ was identified in $\mathrm{H}$. kjellmanii, but was absent in $H$. vitrea (Table 2). $\mathrm{IP}_{25}$ was also found in $H$. crucigeroides and/or $H$. spicula; however, since $H$. crucigeroides and/or H. spicula could not be distinguished during the cell isolation (see Methods section), we are unable to conclude whether both (or only one) of these are $\mathrm{IP}_{25}$ producers. $\mathrm{IP}_{25}$ and other HBIs were absent in cells of $N$. pelagica (Table 2), despite the production of HBIs by some species of Navicula ${ }^{22}$. The absence of $\mathrm{IP}_{25}$ in $\mathrm{N}$. frigida is not surprising, however, since there have been no reports of HBI production in the genus Nitzschia.

In addition to $\mathrm{IP}_{25}$, the structurally related di-unsaturated HBI biomarker $\mathrm{C}_{25: 2} 9$ was also identified in each of the $\mathrm{IP}_{25}$-producing species (Table 2). Previous studies based on the analysis of $\mathrm{IP}_{25}$ in sea ice and sediments have shown a consistent abundance relationship between these two structural homologues indicating a common source at least within the Arctic ${ }^{12,24,33,34}$. Our data not only confirm this source association but, the similarity of the $\mathrm{C}_{25: 2} / \mathrm{IP}_{25}$ ratio in producers $(2.3 \pm 0.8)$ to that found in sea ice and sediments ${ }^{12,24,33,34}$, implies a close link between the source and Arctic sedimentary signatures of these two biomarkers. As such, a significant formation of $\mathrm{IP}_{25}$ over $\mathrm{C}_{25: 2}$ (or vice versa) in sea ice or differential degradation of either biomarker in situ, seems unlikely. Finally, the ranges of intracellular concentrations of $\mathrm{IP}_{25}$ and $\mathrm{C}_{25: 2}$ in the isolated sea ice diatoms were similar between individual species (Table 2) and to those of HBIs measured in culture ${ }^{16}$.

Major $\mathbf{I P}_{25}$-producing taxa. The species selected for lipid analysis corresponded to $\sim 65 \%$ of the total taxa in SIA- 1 , with $\mathrm{IP}_{25}$ producers representing only $1.8 \%$ of the total. As such, the absence of $\mathrm{IP}_{25}$ in the abundant $N$. pelagica and N. frigida corresponded to $\sim 63 \%$ of total cell numbers. Although not all species were investigated (mainly because of low cell numbers of many minor species), these data suggest that the majority of sea ice diatom cells do not synthesize $\mathrm{IP}_{25}$ (Tables 2 and 3), which is consistent with previous lipid-based estimates that indicated only the minority of sea ice flora (1-5\%) likely contribute to $\mathrm{IP}_{25}$ 
Table 1 | Taxonomic composition of diatom aggregates.

\begin{tabular}{|c|c|c|c|c|}
\hline & SIA-1 & SIA-2 & SIA-3 & SIA-4 \\
\hline Amphora laevissima & 1.7 & 1.9 & 2.0 & 0.9 \\
\hline Attheya septentrionalis & 0.7 & 1.3 & 0.4 & 0.9 \\
\hline Bacillaria paxillifera & & 1.1 & & 0.5 \\
\hline Coscinodiscus centralis & & & & 0.1 \\
\hline Cylindrotheca closterium & & 0.1 & 0.2 & \\
\hline Entomoneis gigantean & 0.4 & & 0.2 & \\
\hline Entomoneis kjellmanii & 0.4 & 0.4 & 0.4 & 1.0 \\
\hline${ }^{\star}$ Entomoneis paludosa & 2.0 & 2.0 & 3.8 & 2.2 \\
\hline Fragilariopsis cylindrus & 3.9 & 8.4 & 7.2 & 1.3 \\
\hline Gyrosigma tenuissimum & & & 0.7 & \\
\hline $\begin{array}{l}{ }^{\star} \text { Haslea crucigeroides (and/or Haslea } \\
\text { spicula) }\end{array}$ & 1.4 & 2.4 & 1.8 & 0.2 \\
\hline $\begin{array}{l}\text { Haslea crucigeroides (and/or Haslea } \\
\text { spicula) (empty frustule) }\end{array}$ & & 0.4 & & 0.5 \\
\hline${ }^{\star}$ Haslea kjellmanii & & 0.4 & 0.7 & \\
\hline Haslea kjellmanii (empty frustule) & & 0.1 & 0.2 & \\
\hline${ }^{\star}$ Haslea vitrea & & 0.1 & & \\
\hline Melosira sp. & & & & 0.2 \\
\hline Navicula algida & 0.2 & 0.1 & & 0.1 \\
\hline Navicula cf. trigonocephala & & & & 0.1 \\
\hline Navicula directa & 3.0 & 3.3 & 0.4 & 2.4 \\
\hline Navicula kariana & 0.6 & 0.1 & 0.2 & 0.3 \\
\hline Navicula obtuse & 0.2 & 0.4 & 0.7 & 0.1 \\
\hline *Navicula pelagica & 39.0 & 44.8 & & 52.8 \\
\hline Navicula septentrionalis & & 0.4 & 0.4 & 0.2 \\
\hline Navicula superba & & & 0.2 & \\
\hline Navicula transitans & 0.6 & 0.8 & 2.7 & 0.6 \\
\hline Navicula trigonocephala & 0.2 & & 0.7 & \\
\hline Nitzschia arctica & 3.1 & 2.5 & 6.7 & \\
\hline Nitzschia brebissonii var borealis & & & & 0.1 \\
\hline${ }^{\star}$ Nitzschia frigida & 22.1 & 9.5 & 14.3 & 8.7 \\
\hline Nitzschia laevissima & 0.4 & 1.1 & 4.5 & 0.9 \\
\hline Nitzschia neofrigida & & 0.7 & 4.2 & 2.3 \\
\hline Nitzschia pelagica & & & 14.3 & \\
\hline Nitzschia promare & & 0.1 & 1.1 & \\
\hline Nitzschia seriata & & 0.1 & & \\
\hline Nitzschia sp. & & & 0.4 & \\
\hline $\begin{array}{l}\text { Pauliella taeniata } \\
\text { Phaeocystis sp. }\end{array}$ & 13.0 & 11.5 & 18.0 & $\begin{array}{r}16.1 \\
0.6\end{array}$ \\
\hline Pinnularia quadratarea & 1.5 & 1.1 & 4.0 & 2.0 \\
\hline Pinnularia semiinflata & 0.2 & 0.1 & & \\
\hline Plagiotropis sp. & & & & 0.1 \\
\hline Pleurosigma sp. & & & & 0.1 \\
\hline${ }^{\star}$ Pleurosigma stuxbergii var. rhomboides & 0.4 & 0.8 & 0.2 & 0.1 \\
\hline Pseudogomphonema arcticum & 3.0 & 1.7 & 4.0 & 2.3 \\
\hline Pseudogomphonema groenlandicum & 1.1 & 0.2 & 2.7 & 1.0 \\
\hline Stenoneis inconspicua & 0.4 & & 0.4 & \\
\hline Synedropsis hyperborean & 0.6 & 2.1 & 1.8 & 0.5 \\
\hline Thalassiosira sp. & & & 0.2 & 0.1 \\
\hline Other microorganisms & 0.2 & 0.2 & & 0.3 \\
\hline Total (\%) $\mathrm{IP}_{25}$-producing cells & 1.8 & 3.6 & 2.7 & 0.3 \\
\hline
\end{tabular}

Abundances (\%) of diatoms identified in ice algal aggregates. $\mathrm{IP}_{25}$-producing species are indicated in bold.

${ }^{\star}$ Species analyzed for $\mathrm{IP}_{25}$.

biosynthesis ${ }^{7,16}$. Of course, it remains feasible that some other minor taxa may also be $\mathrm{IP}_{25}$ producers but, given the low percentages of all unexamined species, together with the consistency in cellular abundances of those taxa that are producers, we suggest that their contributions are not significant. In support of this, we note that none of the unexamined genera (Table 1) are known HBI producers.

In order to confirm that H. crucigeroides (and/or H. spicula), H. kjellmanii and P. stuxbergii var. rhomboides indeed represented the majority (at least) of the $\mathrm{IP}_{25}$-producing species, and

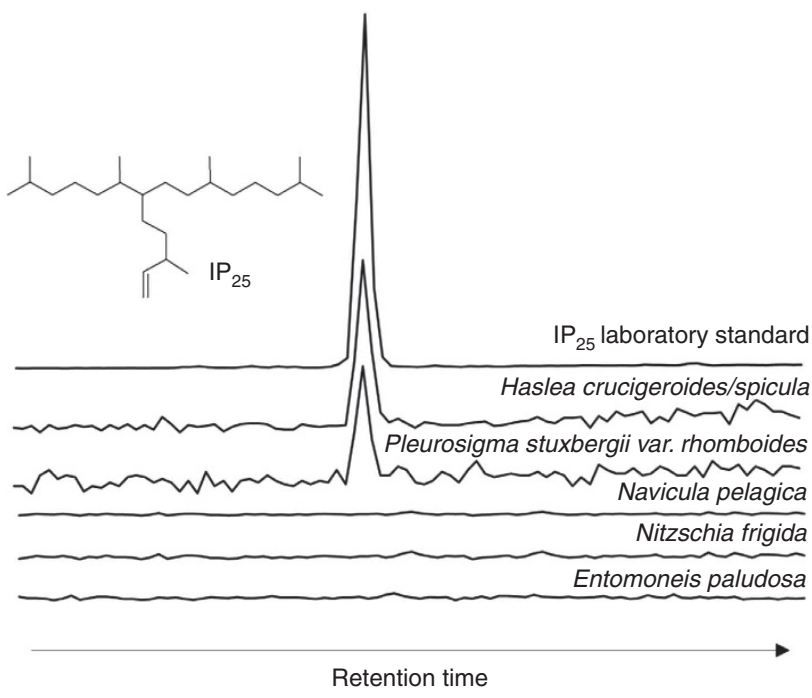

Figure 1 | Lipid extracts from isolated diatoms. Structure of $\mathrm{IP}_{25}$ and partial GC-MS (selective ion monitoring; $m / z$ 350.3) chromatograms of lipid extracts obtained from various diatoms isolated from the mixed assemblages together with that of an authentic sample of $\mathrm{IP}_{25}$ (ref. 57).

that the unanalyzed cells were not significant contributors to the $\mathrm{IP}_{25}$ budget, we calculated the HBI abundance of SIA- 1 relative to the total organic carbon $(\mathrm{TOC})$ content $(\mathrm{HBI} / \mathrm{TOC}=0.05 \%)$ and compared this ratio with the corresponding value obtained from a previously known HBI-producing species (H. ostrearia) in culture $(\mathrm{HBI} / \mathrm{TOC}=1.4 \%)$. The $\sim 30$ times lower contribution of HBIs to sea ice algal TOC compared with that found for cultured diatoms provides a reasonable estimate of the percentage of HBI-producing diatoms in the sea ice algal assemblage $(\sim 3.6 \%)$. This low percentage confirms the relatively small proportion of $\mathrm{IP}_{25}$ producers in the total assemblage, while the close similarity of this estimate to the combined percentages of $H$. crucigeroides (and/or $H$. spicula), $H$. kjellmanii and P. stuxbergii var. rhomboides between SIA-1-4 (Table 2) indicates that these species represent the majority (if not all) of the $\mathrm{IP}_{25}$ producers.

\section{Discussion}

Having identified the major contributors of $\mathrm{IP}_{25}$ in sea ice from a single study location in the Canadian Arctic, we next aimed to address the significance of this discovery with respect to the wider scale applicability of the $\mathrm{IP}_{25}$ biomarker for palaeo sea ice studies. To do this, we compiled literature accounts of $P$. stuxbergii var. rhomboides, $H$. kjellmanii, $H$. crucigeroides and $H$. spicula (note: the latter two as separate species), and compared findings with reports of $\mathrm{IP}_{25}$ in sediments (and sea ice). A summary of the spatial relationship between the two is shown in Fig. 2 .

According to Poulin ${ }^{35}$, Haslea and Pleurosigma are typical of sea ice biota with five common taxa between them. $H$. crucigeroides, $H$. kjellmanii and $H$. spicula are identified as Arctic/sub-Arctic in distribution ${ }^{35}$, while $H$. crucigeroides and $P$. stuxbergii var. rhomboides are the most commonly reported (Table 1). Owing to the close similarity between H. crucigeroides and H. spicula ${ }^{36}$, their occurrences may have been combined in some investigations, as has been the case here for the cell isolation and extraction experiments (see Methods section). Despite their widespread occurrence, however, $H$. crucigeroides, $H$. kjellmanii, H. spicula and P. stuxbergii var. rhomboides are always relatively minor taxa, with abundances usually $<5 \%$ (Table 3 ), as we found here (Table 1). Individual studies have reported these $\mathrm{IP}_{25}$-producing species in first-year 
Table 2 | HBI content of isolated cells.

\begin{tabular}{|c|c|c|c|c|}
\hline Diatom species & Contribution to assemblage (\%) & No. of cells isolated & $\mathrm{IP}_{25}\left(\mathrm{pg}\right.$ cell $\left.{ }^{-1}\right)$ & $C_{25: 2}\left(\mathrm{pg}_{\text {cell }}{ }^{-1}\right)$ \\
\hline Haslea crucigeroides (and/or Haslea spicula) & 1.4 & $200-264$ & $0.6-3.4$ & $1.5-10.3$ \\
\hline Haslea kjellmanii & ND & $40-49$ & $1.9-3.3$ & $4.7-9.0$ \\
\hline Haslea vitrea & ND & 25 & - & - \\
\hline Entomoneis paludosa & 2.0 & 201 & - & - \\
\hline Navicula pelagica & 39.0 & 200 & - & - \\
\hline Nitzschia frigida & 22.1 & 220 & - & - \\
\hline
\end{tabular}

Table 3 | Reported presence of $\mathrm{IP}_{25}$-producing diatoms in sea ice and $\mathrm{IP}_{\mathbf{2 5}}$ in Arctic sediments.

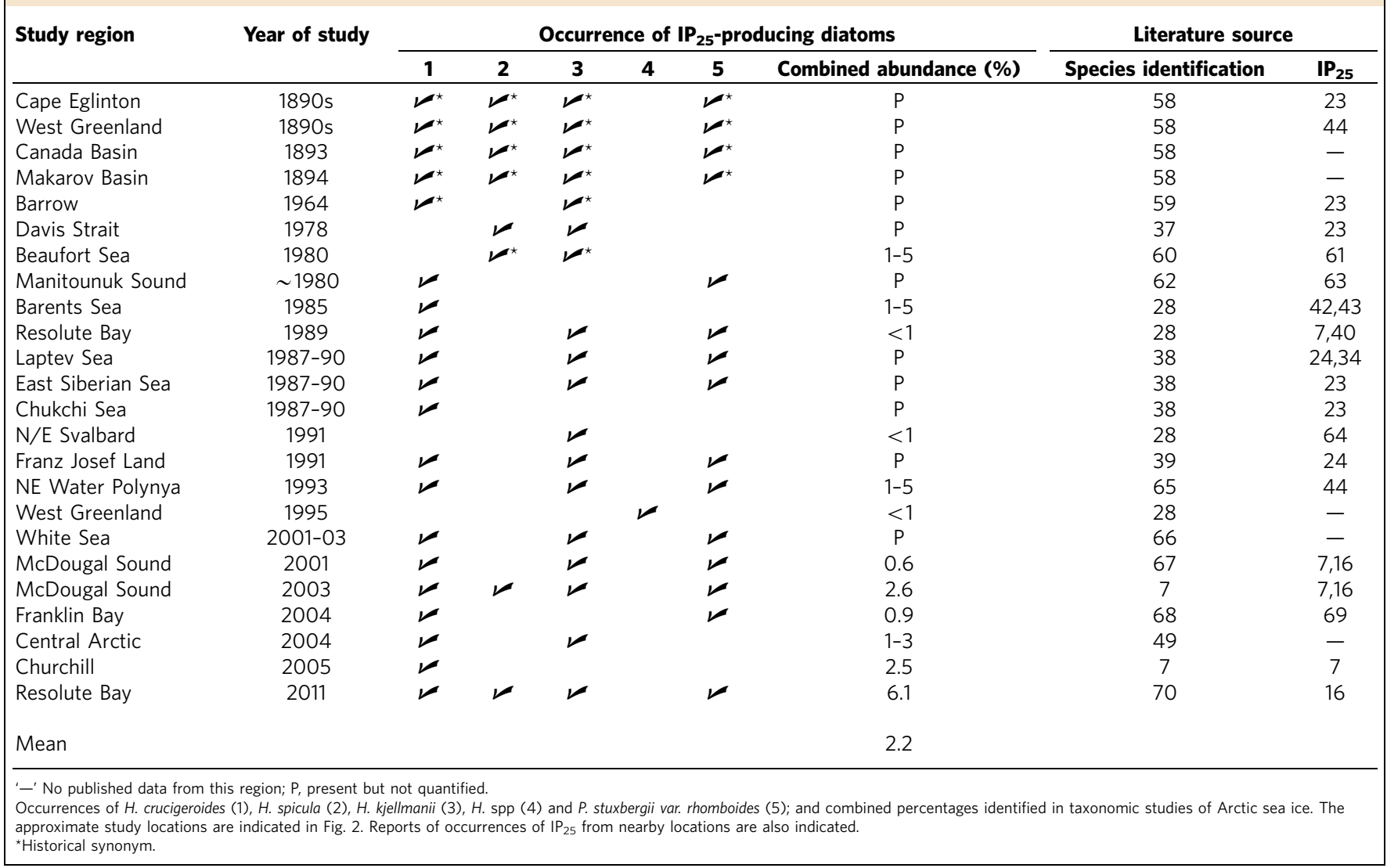

sea ice for locations ranging from 58 to $87^{\circ} \mathrm{N}$, including coastal, shelf and deep ocean environments. Further, such species have been reported in sea ice of varying thickness (for example, $4-300 \mathrm{~cm})^{37,38}$ and type $\mathrm{e}^{28,39}$.

With respect to biomarker-based studies, $\mathrm{IP}_{25}$ has also been reported in surface and downcore sediments from across the Arctic, as reviewed by Belt and Müller ${ }^{9}$, while here, we demonstrate the excellent spatial relationship between occurrences of $\mathrm{IP}_{25}$ in Arctic surface sediments (and sea ice) and reports of the $\mathrm{IP}_{25}$-producing diatoms identified in the current study (Table 3 and Fig. 2). For example, H. crucigeroides, $H$. kjellmanii, $H$. spicula and P. stuxbergii var. rhomboides have been identified in sea ice from across the Canadian Arctic and sub-Arctic (Table 1), and $\mathrm{IP}_{25}$ has been identified as a common component in surface sediments from these regions, with downcore abundances providing the basis for Holocene sea ice reconstructions ${ }^{9,13,40,41}$. Similarly, in the eastern Arctic, where H. crucigeroides, H. kjellmanii, H. spicula and P. stuxbergii var. rhomboides are also common, $\mathrm{IP}_{25}$ occurrence in recent sediments from the Kara, Laptev and Barents Sea shows a strong correlation with modern sea ice cover ${ }^{24,42}$, and this has aided the reconstruction of Holocene (and older) sea ice records from these regions ${ }^{10,43}$. Further, the observation of $\mathrm{IP}_{25}$-producing diatoms in sea ice from around Svalbard and the North East Polynya (NE Greenland) is consistent with the occurrence of $\mathrm{IP}_{25}$ in nearby surface sediments ${ }^{42,44}$, and the longest $\mathrm{IP}_{25}$-based palaeo sea ice records to date are also from this region ${ }^{10,45}$. The majority of these $\mathrm{IP}_{25}$ studies have been conducted in relatively shallow marine settings, proximal to continental shelves while, in contrast, there is currently a paucity of data from deeper oceanographic settings such as the Greenland Sea or the central Arctic Ocean. For the latter, in particular, it has been suggested previously that the combined presence of thick multi-year ice, likely unsuitable for diatom growth, and low sediment accumulation rates may somewhat limit the application of the $\mathrm{IP}_{25}$ proxy method for palaeo sea ice reconstruction ${ }^{9}$. However, 


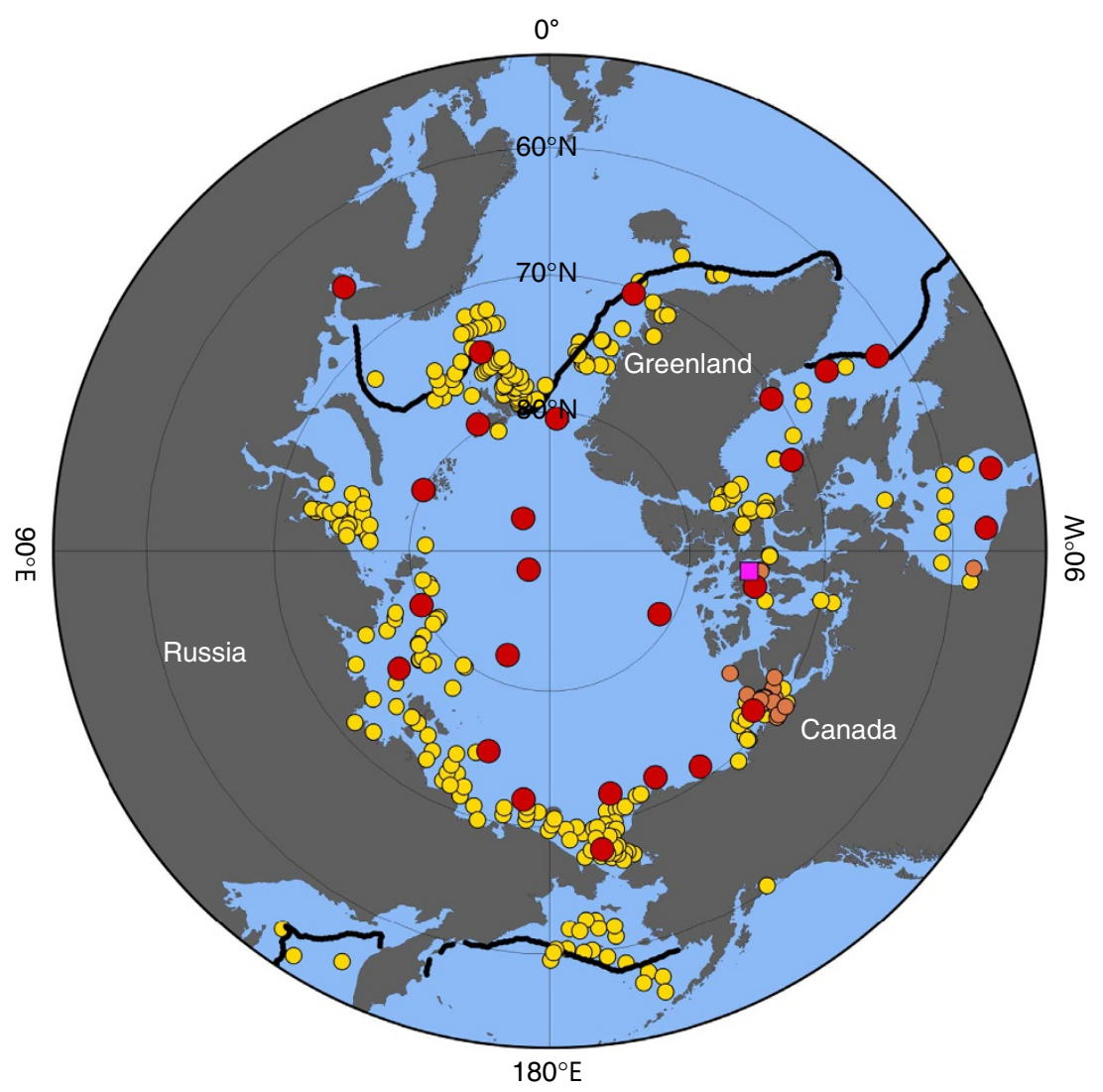

Figure 2 | Distribution of $\mathbf{I P}_{\mathbf{2 5}}$ producers and presence of $\mathbf{I P}_{\mathbf{2 5}}$ in sediments. Summary map showing locations where $\mathrm{IP}_{25}$ has been identified in Arctic surface sediments (yellow circles) and sea ice (orange circles) (Supplementary Data 1). Red circles indicate the approximate locations of sea ice taxonomic studies reporting Haslea spp. and Pleurosigma stuxbergii var. rhomboides (summarized in Table 1). The pink square shows the collection location of the ice algal aggregates analyzed in the current study. The black line shows the median March sea ice extent (National Snow and Ice Data Center; 1981-2010).

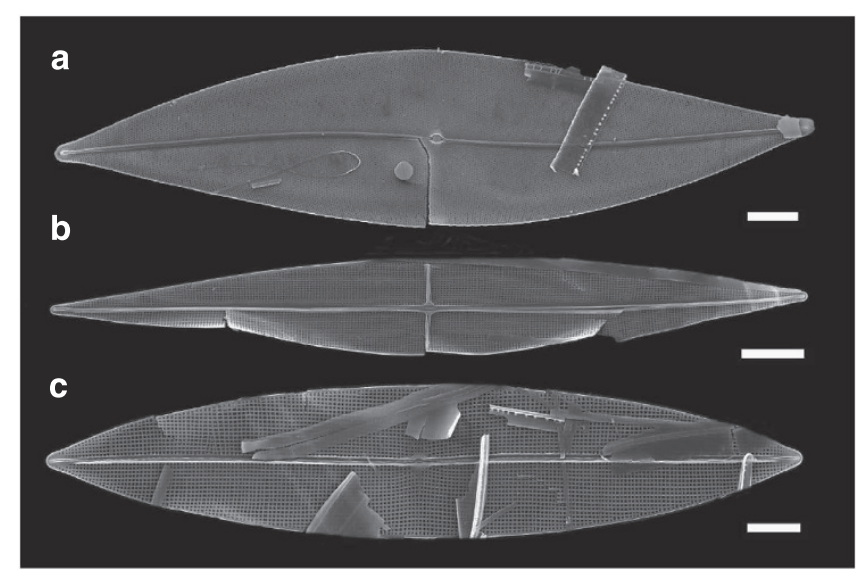

Figure 3 | $\mathbf{I P}_{\mathbf{2 5}}$-producing diatom species. Scanning electron micrographs of $\mathrm{IP}_{25}$-producing diatoms identified in SIA-1. (a) Pleurosigma stuxbergii var. rhomboides; (b) Haslea crucigeroides (and/or Haslea spicula); and (c) Haslea kjellmanii. Scale bars, $10 \mu \mathrm{m}$.

within the context of recent climate change and a reduction in both Arctic sea ice extent and thickness ${ }^{46,47}$, in particular, multi-year ice is becoming increasingly replaced by thinner firstyear ice ${ }^{48}$. Consistent with such a change, we note that some of the $\mathrm{IP}_{25}$ producers identified here have, in fact, been reported in first-year ice within the central Arctic $\left(87^{\circ} \mathrm{N}\right)^{49}$, and $\mathrm{IP}_{25}$ has recently been detected in surface sediments $>80^{\circ} \mathrm{N}$ (X. Xiao and R. Stein, personal communication). We suggest that such observations, in combination with our results here, will likely expand the potential for the $\mathrm{IP}_{25}$ proxy to provide palaeo sea ice reconstruction data for the entire Arctic.

Previously, the identification of $\mathrm{IP}_{25}$ in Arctic sediments has been interpreted as proxy evidence for past seasonal sea ice cover, with variations in sedimentary abundance attributed to corresponding changes in sea ice; an approach supported by a number of meaningful reconstructions ${ }^{9}$. In contrast, the possible influence of ecological controls over $\mathrm{IP}_{25}$ production and their potential impact on its sedimentary abundance have been largely ignored, although its likely importance has been alluded to $7,9,16$. Having now identified those species that are responsible for $\mathrm{IP}_{25}$ formation, it should be possible, in the future, to not only discuss ecological factors when interpreting sedimentary $\mathrm{IP}_{25}$ distributions, but also to test the significance of these experimentally, and in an informed manner.

Here, we suggest that the relatively consistent contribution of $\mathrm{IP}_{25}$ producers to mixed Arctic sea ice diatom assemblages (Table 3) provides some evidence that the larger temporal changes in $\mathrm{IP}_{25}$ concentration often seen in sediments $9,12,13,40,45$ are more likely attributable to sea ice variations than major modifications to diatom assemblage composition, although changes in overall production may still be important. On the other hand, relatively small or subtle variations in sedimentary abundance may, potentially, simply reflect minor changes in species composition or overall production rather than variations in sea ice cover. What is now clear, however, is that since $\mathrm{IP}_{25}$ production is species specific and restricted to the minority 
diatom taxa, conclusions from future investigations into environmental or phenotypic variables over $\mathrm{IP}_{25}$ production will require investigations of specific species, probably via in situ measurements in the field, rather than whole assemblage or simple biomass determinations. In this respect, the discovery of the $\mathrm{IP}_{25}$ producers represents a key step in determining the factors that control the production and fate of $\mathrm{IP}_{25}$, which have been identified as important for its development as a palaeo sea ice proxy $^{9}$.

\section{Methods}

Sample collection. Four floating ice algal aggregates (SIA-1-4) were collected from a sampling hole cut in first-year ice at Resolute Bay in association with the Arctic-ICE (Ice Covered Ecosystems) project (1-9 June $2012 ; 74^{\circ} 43.613^{\prime} \mathrm{N}$; $95^{\circ} 33.496^{\prime}$ W; Fig. 2). Aggregates consisted of sea ice algal assemblages recently sloughed from the underside interstitial channels of first-year ice and were stored in Whirl-Pak bags and frozen $\left(-20^{\circ} \mathrm{C}\right)$. A taxonomic description of the content of sectioned ice cores collected from the same location is given elsewhere ${ }^{16}$.

Species identification. Taxonomic identification of diatom species was carried out on each aggregate (Table 1). Sub-samples of each of SIA-1-4 were freeze-dried, and $\sim 10 \mathrm{mg}$ of dried material was re-suspended in $100 \mathrm{ml}$ of artificial seawater. Aliquots $(0.5 \mathrm{ml})$ were taken for cell enumeration using the Utermöhl method ${ }^{50}$ Cell counts (400-600) were performed on parallel transects using an inverted microscope (Nikon Ti-S) at $\times 60$ magnification ${ }^{51,52}$

More detailed examination of certain taxa was achieved by dry-mounting subsamples of cleaned $\left(10 \% \mathrm{HCl} ; 70^{\circ} \mathrm{C}\right.$ for $30 \mathrm{~min}$ and $3 \times 10 \mathrm{ml}$ Milli-Q washes $)$ cells and examination using a JEOL $7001 \mathrm{~F}$ scanning electron microscope. Specifically, diatoms belonging to the genus Haslea (Fig. 3) were identified based upon general morphological dimensions in addition to features considered characteristic of the genus including, for example, the presence of external longitudinal strips over many areolae, with intervening continuous slits ${ }^{35,53,54}$. Additional characteristic features included elongated helictoglossae, a well-defined accessory rib on the primary side of the raphe sternum and typically straight external raphe fissures with only slight terminal deflection/expansion ${ }^{53}$. Although both $H$. crucigeroides and $H$. spicula were identified in the assemblages as part of the detailed taxonomic analysis (Tatarek, Poland), it was not possible to distinguish between these two species during the low magnification $(\times 40)$ cell isolation stage (Brown, UK) because of the close similarities between them ${ }^{36}$. For P. stuxbergii var. rhomboides, identification was confirmed from the characteristic sigmoidal valve displaying fine striae, with slightly denser oblique than transverse pattern ${ }^{55}$ and equally thickened primary and secondary raphe sternum (cf. Gyrosigma ${ }^{54}$; Fig. 3).

Total organic carbon. Sub-samples $(\sim 50 \mathrm{mg})$ of freeze-dried algae were decarbonated $(10 \% \mathrm{HCl} ; 10 \mathrm{ml})$, washed $(3 \times 10 \mathrm{ml}$ Milli-Q water $)$ and freeze-dried $\left(-80^{\circ} \mathrm{C} ; 0.001 \mathrm{mbar} ; 24 \mathrm{~h}\right)$ before analysis using a Thermoquest EA1110 CHN analyser. L-cystine was used as a calibration standard.

Extraction and analysis of lipids. Lipids were extracted from bulk algal aggregates and combined cells of individual species. For analysis of bulk aggregates, $\sim 50 \mathrm{mg}$ of each aggregate was first washed $(3 \times 10 \mathrm{ml}$ Milli-Q water $)$ to remove marine salts before being freeze-dried $\left(-80^{\circ} \mathrm{C} ; 0.001 \mathrm{mbar} ; 24 \mathrm{~h}\right)$ and re-weighed before extraction. For extractions of individual diatom species, non-washed aggregate sub-samples were re-suspended in $\sim 3 \mathrm{ml}$ filtered $(0.2 \mu \mathrm{m})$ artificial seawater (deionized water; 32 p.p.t. Tropic Marin salt) in a clean glass Petri dish. Individual diatom cells were identified using a Nikon TS2000 inverted light microscope ( $\times 10$ and $\times 40$ objectives) in phase contrast and isolated manually using a modified Pasteur pipette.

Following addition of an internal standard (9-octylheptadec-8-ene; $2 \mu \mathrm{g}$ ), bulk aggregates were saponified $\left(20 \% \mathrm{KOH} ; 80^{\circ} \mathrm{C} ; 60 \mathrm{~min}\right)$ and extracted with hexane according to Brown et al. ${ }^{17}$, whereas for isolated cells a total hexane extract only was obtained (hexane; $3 \times 1 \mathrm{ml}$, ultrasonication; $3 \times 5 \mathrm{~min}$ ). In each case, the resulting total hexane extract suspensions were filtered through pre-extracted (dichloromethane/methanol) cotton wool to remove cells before being partially dried $\left(\mathrm{N}_{2}\right.$ stream) and fractionated into non-polar lipids by column chromatography (hexane $\left.(3 \mathrm{ml}) / \mathrm{SiO}_{2}\right)$.

Analysis of partially purified non-polar lipids was carried out using GC-MS techniques ${ }^{56}$ with minor modifications to increase instrument sensitivity. Identification of $\mathrm{IP}_{25}$ was achieved by a characteristic mass spectral response $(\mathrm{m} / \mathrm{z}$ 350.3; Fig. 1) using selective ion monitoring and co-injection of extracts with an authentic standard of $\mathrm{IP}_{25}$ (ref. 57). Quantification was achieved by integrating the $\mathrm{m} / z 350.3$ ion responses of $\mathrm{IP}_{25}$ and the internal standard in selective ion monitoring mode, and normalizing the ratio between them using an instrumental response factor ${ }^{56}$ and the number of cells extracted.

\section{References}

1. de Vernal, A., Gersonde, R., Goosse, H., Seidenkrantz, M.-S. \& Wolff, E. W. Sea ice in the paleoclimate system: the challenge of reconstructing sea ice from proxies-an introduction. Quat. Sci. Rev. 79, 1-8 (2013).

2. Dieckmann, G. S. \& Hellmer, H. H. in Sea Ice 2nd edn (eds Thomas, D. \& Dieckmann, S.) 1-22 (Blackwell Publishing Ltd, 2010).

3. Vancoppenolle, M. et al. Role of sea ice in global biogeochemical cycles: emerging views and challenges. Quat. Sci. Rev. 79, 207-230 (2013).

4. Andrews, J. T. et al. A robust, multisite Holocene history of drift ice off northern Iceland: implications for North Atlantic climate. Holocene 19, 71-77 (2009).

5. Lisitzin, A. P. Sea-ice and Iceberg Sedimentation in the Ocean, Recent and Past (Springer-Verlag, 2002).

6. Darby, D. A. Sources of sediment found in sea ice from the western Arctic Ocean, new insights into processes of entrainment and drift patterns. J. Geophys. Res. Oceans 108, 3257 (2003).

7. Belt, S. T. et al. A novel chemical fossil of palaeo sea ice: $\mathrm{IP}_{25}$. Org. Geochem. $\mathbf{3 8}$, 16-27 (2007)

8. Robson, J. N. \& Rowland, S. J. Identification of novel widely distributed sedimentary acyclic sesterterpenoids. Nature 324, 561-563 (1986).

9. Belt, S. T. \& Müller, J. The Arctic sea ice biomarker $\mathrm{IP}_{25}$ : a review of current understanding, recommendations for future research and applications in palaeo sea ice reconstructions. Quat. Sci. Rev. 79, 9-25 (2013).

10. Stein, R. \& Fahl, K. Biomarker proxy shows potential for studying the entire Quaternary Arctic sea ice history. Org. Geochem. 55, 98 (2013).

11. Pearce, C. et al. Ocean lead at the termination of the Younger Dryas cold spell Nat. Commun. 4, 1664 (2013).

12. Cabedo-Sanz, P., Belt, S. T., Knies, J. \& Husum, K. Identification of contrasting seasonal sea ice conditions during the Younger Dryas. Quat. Sci. Rev. 79, 74-86 (2013).

13. Müller, J. et al. Holocene cooling culminates in sea ice oscillations in Fram Strait. Quat. Sci. Rev. 47, 1-14 (2012).

14. Vare, L. L., Massé, G. \& Belt, S. T. A biomarker-based reconstruction of sea ice conditions for the Barents Sea in recent centuries. Holocene 20, 637-643 (2010).

15. Massé, G. et al. Abrupt climate changes for Iceland during the last millennium: Evidence from high resolution sea ice reconstructions. Earth Planet. Sci. Lett. 269, 565-569 (2008).

16. Belt, S. T. et al. Quantitative measurement of the sea ice diatom biomarker $\mathrm{IP}_{25}$ and sterols in Arctic sea ice and underlying sediments: further considerations for palaeo sea ice reconstruction. Org. Geochem. 62, 33-45 (2013).

17. Brown, T. A. et al. Temporal and vertical variations of lipid biomarkers during a bottom ice diatom bloom in the Canadian Beaufort Sea: further evidence for the use of the $\mathrm{IP}_{25}$ biomarker as a proxy for spring Arctic sea ice. Polar Biol. 34, 1857-1868 (2011).

18. Belt, S. T., Cooke, D. A., Robert, J. M. \& Rowland, S. Structural characterisation of widespread polyunsaturated isoprenoid biomarkers: $\mathrm{A} \mathrm{C}_{25}$ triene, tetraene and pentaene from the diatom Haslea ostrearia simonsen. Tetrahedron Lett. 37, 4755 (1996).

19. Allard, W. G. et al. Tetra-unsaturated sesterterpenoids (Haslenes) from Haslea ostrearia and related species. Phytochemistry 56, 795-800 (2001).

20. Grossi, V. et al. $\mathrm{C}_{25}$ highly branched isoprenoid alkene from the marine benthic diatom Pleurosigma strigosum. Phytochemistry 65, 3049-3055 (2004).

21. Belt, S. T., Allard, W. G., Massé, G., Robert, J. M. \& Rowland, S. J. Highly branched isoprenoids (HBIs): Identification of the most common and abundant sedimentary isomers. Geochim. Cosmochim. Acta 64, 3839-3851 (2000).

22. Belt, S. T., Massé, G., Allard, W. G., Robert, J. M. \& Rowland, S. J. Identification of a $\mathrm{C}_{25}$ highly branched isoprenoid triene in the freshwater diatom Navicula sclesvicensis. Org. Geochem. 32, 1169-1172 (2001).

23. Stoynova, V., Shanahan, T. M., Hughen, K. A. \& de Vernal, A. Insights into Circum-Arctic sea ice variability from molecular geochemistry. Quat. Sci. Rev. 79, 63-73 (2013).

24. Xiao, X., Fahl, K. \& Stein, R. Biomarker distributions in surface sediments from the Kara and Laptev seas (Arctic Ocean): indicators for organic-carbon sources and sea-ice coverage. Quat. Sci. Rev. 79, 40-52 (2013).

25. Volkman, J. K., Barrett, S. M. \& Dunstan, G. A. $\mathrm{C}_{25}$ and $\mathrm{C}_{30}$ highly branched isoprenoid alkenes in laboratory cultures of two marine diatoms. Org. Geochem. 21, 407-414 (1994).

26. Smol, J. P. \& Stroermer, E. F. The Diatoms: Applications for the Environmental and Earth Sciences, 2nd edn (Cambridge University Press, 2010).

27. Assmy, P. et al. Floating ice-algal aggregates below melting Arctic sea ice. PLoS ONE 8, e76599 (2013).

28. von Quillfeldt, C. H. Common diatom species in Arctic spring blooms: their distribution and abundance. Bot. Mar. 499 (2000).

29. Massé, G. Highly Branched Isoprenoid Alkenes from Diatoms: A Biosynthetic and Life Cycle Investigation: Ph.D thesis (University of Plymouth, 2003). 
30. Massé, G., Belt, S. T., Rowland, S. J. \& Rohmer, M. Isoprenoid biosynthesis in the diatoms Rhizosolenia setigera (Brightwell) and Haslea ostrearia (Simonsen). Proc. Natl Acad. Sci. USA 101, 4413-4418 (2004).

31. Sinninghe Damsté, J. S. et al. The rise of the Rhizosolenid diatoms. Science 304, 584-587 (2004).

32. Belt, S. T., Allard, W. G., Massé, G., Robert, J. M. \& Rowland, S. J. Important sedimentary sesterterpenoids from the diatom Pleurosigma intermedium. Chem. Commun. 501-502 (2000).

33. Massé, G. et al. Highly branched isoprenoids as proxies for variable sea ice conditions in the Southern Ocean. Antarct. Sci. 23, 487-498 (2011).

34. Fahl, K. \& Stein, R. Modern seasonal variability and deglacial/Holocene change of central Arctic Ocean sea-ice cover: New insights from biomarker proxy records. Earth Planet. Sci. Lett. 351-352, 123-133 (2012).

35. Poulin, M. in Polar marine Diatoms. (eds Medlin, L. K. \& Priddle, J.) 137-149 (British Antarctic Survey, 1990).

36. Poulin, M. \& Cardinal, A. Sea ice diatoms from Manitounuk Sound, Southeastern Hudson Bay (Quebec, Canada) I. Family Naviculaceae. Can. J. Bot. 60, 1263-1278 (1982)

37. Booth, J. A. The epontic algal community of the ice edge zone and its significance to the Davis Strait ecosystem. Arctic 37, 234-243 (1984).

38. Okolodkov, Y. B. Cryopelagic flora of the Chukchi, East Siberian and Laptev Seas. Proc. NIPR Symp. Polar Biol. 1992 5, 28-43 (1992).

39. Okolodkov, Y. B. Algae in the annual sea ice at Hooker Island, Franz Josef Land, in August 1991. Polish Polar Res. 14, 25-32 (1993).

40. Vare, L. L., Massé, G., Gregory, T. R., Smart, C. W. \& Belt, S. T. Sea ice variations in the central Canadian Arctic Archipelago during the Holocene. Quat. Sci. Rev. 28, 1354-1366 (2009).

41. Belt, S. T. et al. Striking similarities in temporal changes to seasonal sea ice conditions across the central Canadian Arctic Archipelago during the last 7,000 years. Quat. Sci. Rev. 29, 3489-3504 (2010).

42. Navarro-Rodriguez, A., Belt, S. T., Knies, J. \& Brown, T. A. Mapping recent sea ice conditions in the Barents Sea using the proxy biomarker $\mathrm{IP}_{25}$ : implications for palaeo sea ice reconstructions. Quat. Sci. Rev. 79, 26-39 (2013).

43. Berben, S. M. P., Husum, K., Cabedo-Sanz, P. \& Belt, S. T. Holocene sub centennial evolution of Atlantic water inflow and sea ice distribution in the western Barents Sea. Clim. Past Discuss. 9, 4893-4938 (2013).

44. Müller, J. et al. Towards quantitative sea ice reconstructions in the northern North Atlantic: A combined biomarker and numerical modelling approach. Earth Planet. Sci. Lett. 306, 137-148 (2011).

45. Müller, J., Massé, G., Stein, R. \& Belt, S. T. Variability of sea-ice conditions in the Fram Strait over the past 30,000 years. Nat. Geosci. 2, 772-776 (2009).

46. Comiso, J. C., Parkinson, C. L., Gersten, R. \& Stock, L. Accelerated decline in the Arctic sea ice cover. Geophys Res. Lett. 35, L01703 (2008).

47. Wadhams, P. in Environmental Security in the Arctic Ocean. (eds Berkman, P. A. \& Vylegzhanin, A. N.) 15-30 (Springer, 2013).

48. Parkinson, C. L. \& Comiso, J. C. On the 2012 record low Arctic sea ice cover: Combined impact of preconditioning and an August storm. Geophys. Res. Lett. 40, 1356-1361 (2013).

49. Katsuki, K., Takahashi, K., Onodera, J., Jordan, R. W. \& Suto, I. Living diatoms in the vicinity of the North Pole, summer 2004. Micropaleontology 55, 137-170 (2009).

50. UNESCO. Monographs on Oceanographic Methodology. UNESCO (1978).

51. Tomas, C. R. Identifying Marine Phytoplankton, Florida Department of Enviromentl Protection (Florida Marine Research Institute, 1997).

52. Berard-Therriault, L., Poulin, M. \& Bosse, L. Guide d'identification du phytoplancton marin de l'estuaire et du golfe du Saint- Laurent, Publication speciale canadienne des siences halieutiques et aquatiques 128 (1999).

53. Massé, G. et al. Haslea salstonica sp. nov. and Haslea pseudostrearia sp. nov. (Bacillariophyta), two new epibenthic diatoms from the Kingsbridge estuary, United Kingdom. Comptes Rendus de l'Académie des Sciences - Series III Sciences de la Vie 324, 617-626 (2001).

54. Round, F. E., Crawford, R. M. \& Mann, D. G. The Diatoms: Biology and Morphology of the Genera (Cambridge University Press, 1990).

55. Sterrenburg, F. A. S. Studies on the genera Gyrosigma and Pleurosigma (Bacillariophyceae). The identity of Pleurosigma obscurum W. Smith. Diatom Res. 8, 447-456 (1993).

56. Belt, S. T. et al. A reproducible method for the extraction, identification and quantification of the Arctic sea ice proxy $\mathrm{IP}_{25}$ from marine sediments. Anal. Methods 4, 705-713 (2012).

57. Belt, S. T., Brown, T. A., Cabedo Sanz, P. \& Navarro Rodriguez, A. Structural confirmation of the sea ice biomarker $\mathrm{IP}_{25}$ found in Arctic marine sediments. Environ Chem. Lett. 10, 189-192 (2012).
58. Gran, H. H. Diatomaceae from the ice-floes and plankton of the Arctic Ocean. Sci. Res. Norw. North Polar Exped. 11, 1-74 (1904).

59. Meguro, H., Ito, K. \& Fukushima, H. Ice flora (bottom type): a mechanism of primary production in polar seas and the growth of diatoms in sea ice. Arctic 20, 114-133 (1967).

60. Horner, R. \& Schrader, G. C. Relative contributions of ice algae, phytoplankton, and benthic microalgae to primary production in nearshore regions of the Beaufort Sea. Arctic 35, 485-503 (1982).

61. Tolosa, I., Fiorini, S., Gasser, B., Martín, J. \& Miquel, J. C. Carbon sources in suspended particles and surface sediments from the Beaufort Sea revealed by molecular lipid biomarkers and compound-specific isotope analysis. Biogeosciences 10, 2061-2087 (2013).

62. Poulin, M. \& Cardinal, A. Sea ice diatoms from Manitounuk Sound, Southeastern Hudson Bay (Quebec, Canada). II. Family Naviculaceae, genus Navicula. Can. J. Bot. 60, 2825-2845 (1982).

63. Brown, T. A. et al. Identification of the sea ice diatom biomarker $\mathrm{IP}_{25}$ and related lipids in marine mammals: A potential method for investigating regional variations in dietary sources within higher trophic level marine systems. J. Exp. Mar. Biol. Ecol. 441, 99-104 (2013).

64. Brown, T. A., Hegseth, E. N. \& Belt, S. T. A biomarker-based investigation of the mid-winter ecosystem in Rijpfjorden, Svalbard. Polar Biol. doi:10.1007/ s00300-013-1352-2 (2013).

65. von Quillfeldt, C. H. Distribution of diatoms in the Northeast Water Polynya Greenland. J. Mar. Syst. 10, 211-240 (1997).

66. Ratkova, T. N. \& Wassmann, P. Sea ice algae in the White and Barents Seas: composition and origin. Polar Res. 24, 95-110 (2005).

67. Riedel, A., Michel, C., Poulin, M. \& Lessard, S. Canadian Data Report of Hydrography and Ocean Sciences. Report No. 159, 54p (Freshwater Institute FaOC, Winnipeg, MB, Canada, 2003).

68. Różanska, M., Gosselin, M., Poulin, M., Wiktor, J. M. \& Michel, C. Influence of environmental factors on the development of bottom ice protist communities during the winter-spring transition. Mar. Ecol. Prog. Ser. 386, 43-59 (2009).

69. Brown, T. A. \& Belt, S. T. Identification of the sea ice diatom biomarker $\mathrm{IP}_{25}$ in Arctic benthic macrofauna: direct evidence for a sea ice diatom diet in Arctic heterotrophs. Polar Biol. 35, 131-137 (2012).

70. Galindo, V. et al. Biological and physical processes influencing sea ice, underice algae, and dimethylsulfoniopropionate during spring in the Canadian Arctic Archipelago. J. Geophys. Res.: Oceans doi: 10.1002/2013JC009497 (2014).

\section{Acknowledgements}

We thank the University of Plymouth for a Fellowship to T.A.B. We also thank J. Wiktor (Institute of Oceanology, Polish Academy of Sciences) and Michel Poulin (Canadian Museum of Nature) for their taxonomical assistance. We also thank Peter Bond at the University of Plymouth Electron Microscopy Centre for assistance with the scanning electron microscope. We are especially grateful to Michel Gosselin (Université du Québec à Rimouski) for providing additional field support under the Arctic-ICE programme, and Alexis Burt (University of Manitoba) for collecting aggregate samples. Sample collection was supported through a Natural Sciences and Engineering Research Council of Canada (NSERC) Discovery grant to C.J.M., and by the Polar Continental Shelf Program (PCSP) of Natural Resources Canada. This is a contribution to the research programs of ArcticNet, Arctic Science Partnership (ASP) and the Canada Excellence Research Chair unit at the Centre for Earth Observation Science.

\section{Author contributions}

T.A.B. designed and implemented the study, performed lipid analyses and data synthesis; A.T. carried out taxonomic assessments of samples; T.A.B. and S.T.B. wrote the manuscript with significant input from C.J.M.

\section{Additional information}

Supplementary Information accompanies this paper at http://www.nature.com/ naturecommunication

Competing financial interests: The authors declare no competing financial interests

Reprints and permission information is available online at http://npg.nature.com/ reprintsandpermissions/

How to cite this article: Brown, T. A. et al. Source identification of the Arctic sea ice proxy $\mathrm{IP}_{25}$. Nat. Commun. 5:4197 doi: 10.1038/ncomms5197 (2014). 